\title{
ANALISIS KELAYAKAN USAHA COKELAT PRALINE DENGAN METODE CAPITAL BUDGETING DI TOKO KUE BAPER COKELAT PAMULANG
}

\author{
Aod Abdul Jawad \\ Fakultas Teknik Industri Universitas Pamulang \\ dosen02273@unpam.ac.id
}

\begin{abstract}
ABSTRAK
Toko Kue Baper Cokelat merupakan salah satu bentuk usaha perorangan yang salah satu produk andalannya adalah cokelat praline. Pada penelitian ini penulis membahas mengenai kelayakan usaha cokelat praline pada aspek pemasaran, teknis dan keuangan. Penulis menganalisa data keuangan toko dalam periode Januari 2018 sampai dengan Desember 2018. Metode yang digunakan adalah Capital Budgeting. Dari hasil analisa dalam periode Januari sampai dengan Desember 2018, didapat hasil usaha cokelat praline pantas dijalankan. Mengacu pada perhitungan Tingkat Pengembalian rata-rata (ARR) didapatkan nilai 132,09\% lebih besar daripada tingkat cost of capital 7,37\%, Net Present Value (NPV) positif bernilai Rp 216,643,572.14, Profitability Index diperoleh nilai 3,13 sesuai persyaratan harus lebih dari 1 ,Tingkat pengembalian Investasi (IRR) menghasilkan nilai 23,06\% lebih besar dari tingkat suku bunga terendah 5,75\%, Periode Pengembalian Investasi didapatkan hasil pengembalian dalam jangka waktu 3 tahun 2 bulan 13 hari.
\end{abstract}

Kata Kunci: Kewirausahaan, Studi Kelayakan, Cokelat Praline, Capital Budgeting

\section{PENDAHULUAN}

Di era globalisaasi saat ini, banyak masyarakat berlomba mendirikan suatu usaha dalam rangka memenuhi kebutuhan hidupnya.

Salah satu bentuk sebuah wirausaha yakni usaha pengolahan cokelat. Cokelat adalah sebutan untuk hasil olahan makanan atau minuman dari biji kakao (Theobroma Cacao). Cokelat di zaman sekarang, pada umumnya diberikan sebagai hadiah atau bingkisan di hari raya. Selain itu, cokelat praline ini dapat dijadikan sebagai souvenir maupun hadiah untuk acara-acara tertentu, baik formal maupun non formal. Cokelat Praline merupakan salah satu olahan cokelat dengan bentuk dan rasa yang beraneka ragam. Selain rasa dan warna yang dapat dikreasikan sesuai selera, packaging nya pun dapat dikreasikan sesuai kebutuhan.

Setiap usaha memerlukan pemahaman layak atau tidak layak usaha tersebut untuk di bangun. Dalam penelitian ini, studi kelayakan usaha merupakan suatu metode atau cara yang terdiri dari berbagai aspek penilaian untuk mengetahui apakah suatu usaha yang akan dikerjakan layak atau tidak. Sehingga dapat dikatakan juga suatu alat peramalan yang sangat mumpuni untuk mengetahui kemungkinan-kemungkinan yang akan terjadi, serta dapat segera mengambil keputusan atas hasil yang diperoleh yakni menerima atau menolak usaha tersebut.

Studi kelayakan usaha dilakukan untuk melihat sejauh mana tingkat kelayakan usaha cokelat praline, sejauh mana pemasaran dari produk yang dihasilkan dapat mendukung perkembangan usaha yang akan dilaksanakan.

\section{DASAR TEORI}

$$
\text { Cokelat Praline Menurut }
$$

Suratmono (2017:2), Cokelat Praline merupakan salah satu bentuk permen cokelat yang terbuat dari cokelat, mentega yang disajikan dalam bentuk beraneka ragam yang isinya seperti kacang, buah dan lainlain.

Kewirausahaan menurut pendapat Yuniarta (2015:01), Kewirausahaan adalah 
kemampuan untuk menciptakan sesuatu yang baru dan berbeda, melalui pemikiran kreatif dan tindakan inovatif, demi terciptanya sebuah peluang. Banyak orang, baik pengusaha maupun yang bukan pengusaha, dapat meraih kesuksesan karena memiliki kemampuan berpikir kreatif dan inovatif.

Menurut Busro (2017:2), Studi Kelayakan Bisnis merupakan suatu proses awal yang dilakukan oleh seorang calon pengusaha baik usaha besar maupun usaha kecil, mulai dari menentukan jenis usaha, tempat usaha, jumlah modal, jumlah karyawan, keahlian karyawan, perkiraan kembali modal, untung yang diharapkan, prospek masa depan, khalayak sasaran, mitra usaha yang hendak dipilih, wilayah kerja atau lokasi pemasaran, sumber mendapatkan bahan baku atau barang dagangan, dan berbagai hal yang harus disiapkan sehingga usaha bisnis dapat dilakukan.

Menurut Yuniarta (2015:317), tahap-tahap dalam melakukan studi kelayakan usaha terdiri dari:

1. Pengumpulan Data dan Informasi

2. Pengolahan Data

3. Analisis Data

4. Mengambil Keputusan

5. Memberikan Rekomendasi

Pada penelitian ini, peneliti hanya menggunakan 3(tiga) aspek dalam studi kelayakan usaha, yakni:

1. Aspek Pasar dan Pemasaran

2. Aspek Teknis

3. Aspek Keuangan

\section{A. Pengertian Capital Budgeting}

$$
\text { Menurut Riyanto (121:2015) }
$$
Capital Budgeting adalah keseluruhan proses perencanaan dan pengambilan keputusan mengenai pengeluaran dana dimana jangka waktu kembalinya dana tersebut melebihi waktu satu tahun. Batas waktu satu tahun tersebut tidaklah mutlak, termasuk dalam pengeluaran dana ini adalah pengeluaran dana untuk pembelian aktiva, yaitu tanah, bangunan, mesin, alat-alat lainnya.

\section{B. Tujuan Capital Budgeting}

Tujuan Perusahaan yang menerapkan capital budgeting terlebih dahulu harus menentukan apa yang menjadi tujuan dari adanya capital budgeting. Karena tujuan dari capital budgeting merupakan cara untuk mengevaluasi layak atau tidaknya suatu usulan rencana proyek. Secara garis besar, tujuan capital budgeting antara lain:

1. Untuk memaksimumkan kekayaan para pemegang saham (memaksimumkan nilai tukar perusahaan). Artinya dengan adanya penganggaran modal maka sebuah perusahaan sebaiknya beroperasi pada tingkat dimana pendapatan marginal sama dengan biaya marginalnya. Pendapatan marginalnya diartikan sebagai tingkat hasil pengambilan investasi, sedangkan biaya marginal diartikan sebagai biaya modal marginal perusahaan.

2. Untuk dapat memilih saat yang tepat dalam memperoleh atau kembali aktiva dan mutu aktiva yang dibeli. Hal ini sesuai dengan sifat barang modal dan para produsennya. Barang modal tidak dipesan oleh perusahaan sebelum tampak adanya peningkatan penjualan sehingga dirasakan kekurangan kapasitas.

\section{Metode dalam Capital Budgeting}

Metode yang digunakan dalam Capital Budgeting ialah:

1. Tingkat Pengembalian rata-rata (Average Rate of Return)

Dalam menghitung Tingkat pengembalian rata-rata dapat dihitung atas jumlah keuntungan bersih sesudah pajak (EAT) yang terdapat dalam laba rugi. Perhitungannya adalah sebagai berikut:

$$
\text { Average of Return }=\frac{\text { Average Earning After Taxes }}{\text { Average Investment }}
$$

\section{Periode Pengembalian (Payback Period)}

Metode ini dalam penggunaannya ada beberapa faktor yang sangat menentukan dalam penerimaan atau penolakan ususkan investasi yaitu jangka waktu yang diperlukan dalam rangka menutup kembali suatu investasi. Maka dari itu, penggunaan metode ini sebuah usulan investasi dapat dinilai berdasarkan jangka waktu yang telah ditentukan oleh suatu organisasi perusahaan dan sesuai dengan keinginan manajemen tentunya, 
arus kas dan atau suatu penghematan yang diperoleh dari investasi yang sudah ditanamkan dapat tertutupi oleh investasi yang direncanakan. Periode Pengembalian ini juga merupakan penggambaran berapa hari yang dibutuhkan untuk mengembalikan biaya investasi yang sudah ditanamkan melalui arus kas.

$$
\text { Payback Period }=\frac{\text { Initial Investment }}{\text { cashflow }}
$$

\section{Net Present Value (NPV)}

Net present value secara pengertiannya adalah nilai selisih antara cash flow yang di berupa potongan atau bunga yang harus dibayar oleh orang yang menjual surat dagang yang diuangkan sebelum waktunya (diskonto) pada minimum tingkat bunga atau juga sering disebut cost of capital perusahaan. Net present value merupakan suatu cara menghitung nilai sekarang dari arus kaspada sebuah operasi dengan menentukan tingkat keuntungan kemudian dikurangi dengan kas yang keluar pada neto pertama.

$$
N P V=-I o+\sum \frac{A t}{(1+r)^{t}}
$$

Dimana:

Io = nilai Investasi atau outlays

$\mathrm{At}=$ Aliran kas neto pada periode $\mathrm{t}$

$\mathrm{r}=$ discount rate

$\mathrm{t}=$ Umur proyek

4. Indikator tingkat Investasi (Internal Rate of Return)

Indikator tingkat Investasi (Internal Rate of Return) yaitu merupakan suatu tingkat indikator efisiensi dari sebuah investasi yang dihitung dari kas yang tersedia dengan jumlah investasi pertama dari sebuah proyek yang sedang dilakukan. Arti lainnya dari IRR adalah tingkat diskon yang membuat nilai NPV sama dengan nol, karena pada tingkat ini, nilai NPV saat discount akan sama dengan investasi pertama (initial investment)
5. Indeks Keuntungan (Profitability Index)

Indeks Keuntungan juga sering dikenal dengan rasio invesasi laba dan rasio investasi awal. Indeks Keuntungan menandakan sebuah investasi suatu proyek dengan tingkat pemgembaliannya sesuai dengan yang diinginkan atau ditetapkan sebelumnya. Metode ini juga merupakan sebuah alat yang dapat menentukan peringkat proyek yang memungkinkan pengukuran dari nilai yang dibuat dalam sebuah unit.

\section{METODE DAN TEKNIK PENGUKURAN}

Teknik pengumpulan data yang dilakukan adalah sebagai berikut:

1. Observasi

Metode observasi merupakan metode yang sistematis dengan pelaksanaan teknisnya yaitu mengamati objek secara langsung aktual sehingga mendapat gambaran nyata atau objektif.

2. Wawancara

Metode wawancara merupakan data yang dikumpulkan sendiri oleh peneliti yang berhubungan dengan penelitian yang sedang diaksanakan berupa pengajuan beberapa pertanyaan secara langsung kepada narasumber atau autoritas dengan pemilik usaha pada penelitian yang sedang diteliti.

\section{Dokumentasi}

Pengumpulan data dengan mempelajari dokumen-dokumen yang ada serta catatan-catatan yang berhubungan dengan objek yang sedang diteliti.

\section{Kepustakaan}

Metode ini meruakan suatu teknik dalam pengumpulan data dengan membaca literatur, buku terbitan, artikel, dan referensi lain yang relevan dengan objek penelitian ini. 
Definisi operasional adalah batasan pengertian tentang variabel yang diteliti yang didalamnya sudah mencerminkan indikator-indikator yang akan digunakan untuk mengukur variabel yang bersangkutan. Variabel yang digunakan dalam penelitian ini yaitu Accounting Rate of Return, Payback Period, Net Present Value, Profitability Index, Internal Rate of Return, dan kelayakan usaha yang dianalisis dengan menggunakan metode Capital Budgeting. Tabel 3.1 berikut ini merupakan Variabel Definisi Operasi dalam penelitian.

Tabel 3.1 Variabe Definisi Operasi

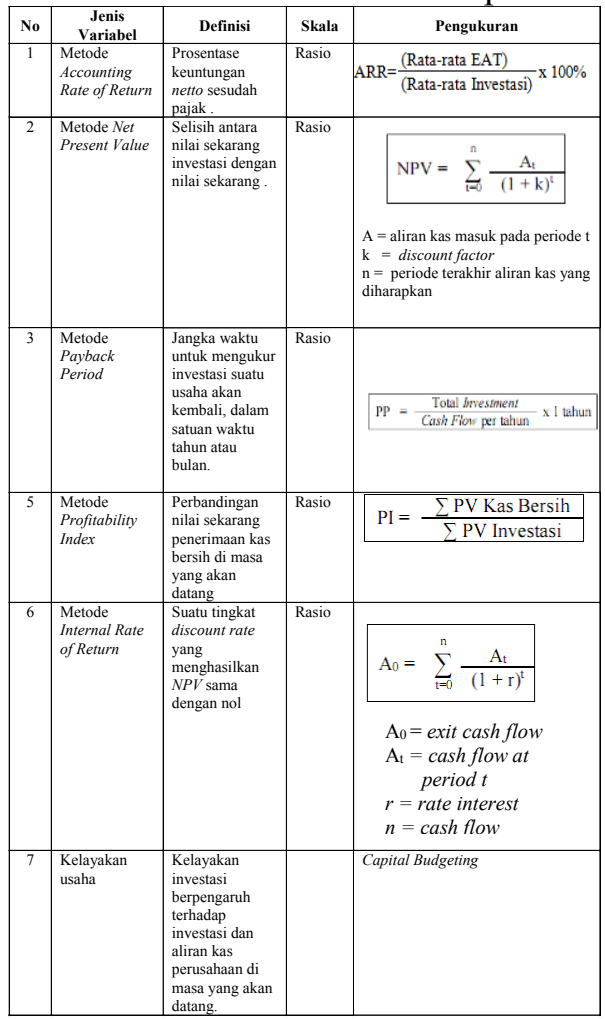

(Sumber: Pengolahan dari berbagai sumber)

\section{HASIL DAN PEMBAHASAN}

\section{A. Aspek Pasar dan Pemasaran}

\section{Potensi Pasar}

Pasar-pasar potensial yang dimiliki oleh Toko Baper Cokelat antara lain perusahaan-perusahaan di sekitar lokasi, pengusaha souvenir, dan lain sebagainya. Gambar 4.4 berikut ini merupakan perkembangan produksi cokelat praline di Toko Kue Baper Cokelat dari tahun 2017 sampai dengan tahun 2018

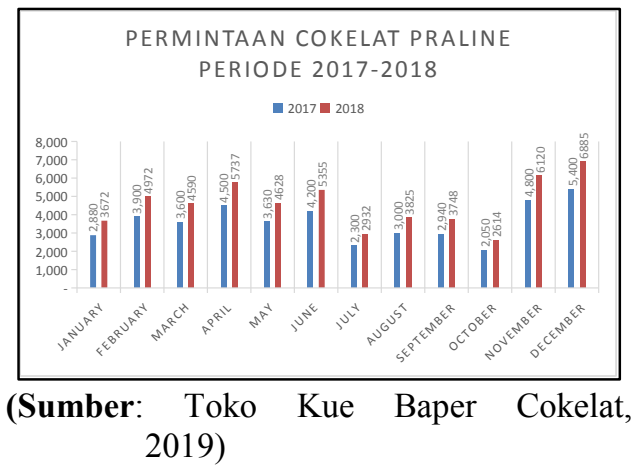

Gambar 4.4 Potensi Pasar Cokelat Praline

\section{Analisis SWOT}

Analisa SWOT mencakup lingkungan internal dan eksternal perusahaan. Tabel 4.1 merupakan faktor internal dari Toko Kue Baper Cokelat. pada Tabel 4.1

Tabel 4.1 Faktor Internal

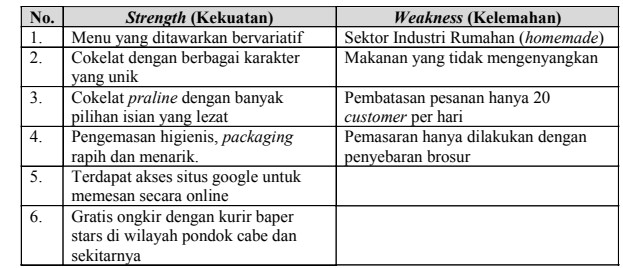

(Sumber: Toko Kue Baper Cokelat, 2019)

Selain faktor internal, Tabel $\mathbf{4 . 2}$ juga menunjukkan faktor eksternal Toko Kue Baper Cokelat.

Tabel 4.2 Faktor Eksternal

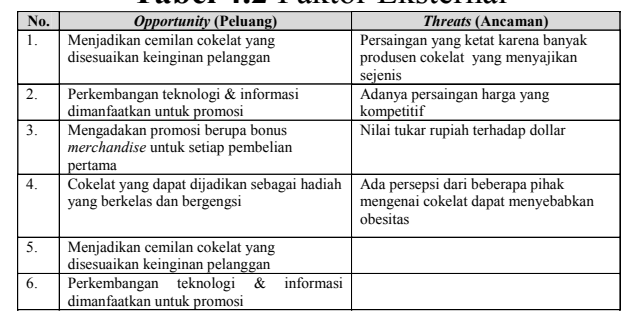

(Sumber: Pengolahan Penelitian,2019)

Langkah selanjutnya setelah faktor teridentifikasi adalah perhitungan bobot dan rating, penentuan bobot didasarkan pada angka $0-1$. Nilai pada bobot ditentukan dari hasil wawancara antara penulis dengan pemilik perusahaan. Sedangkan penentuan rating berdasarkan tingkat pengaruh faktor tersebut terhadap perusahaan. Rating dari 1 
sampai dengan 4, paling berpengaruh memiliki rating 1 , sedangkan rating 4 merupakan yang paling sedikit berpengaruh. Penentuan rating tersebut berdasarkan diskusi dengan pemilik perusahaan. Tabel $\mathbf{4 . 3}$ berikut ini merupakan perhitungan bobot dan rating Toko Kue Baper Cokelat

Tabel 4.3 Perhitungan Bobot Matriks IFAS

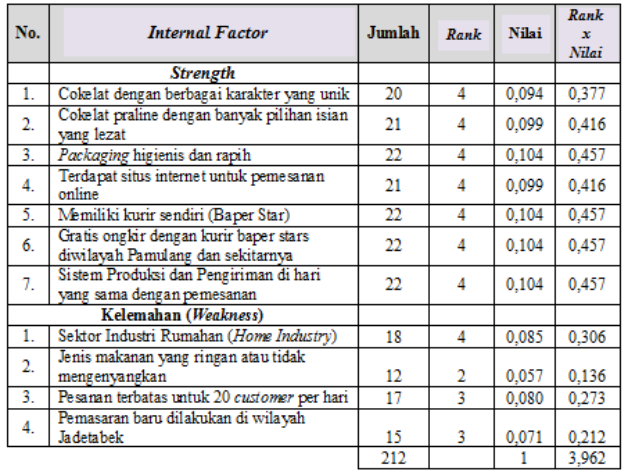

(Sumber: Pengolahan data, 2019)

Tabel 4.4 Perhitungan Matriks EFAS

\begin{tabular}{|c|c|c|c|c|c|}
\hline No. & External Factor & Jumlah & Rank & Nilai & \begin{tabular}{|c|} 
Rank \\
$\mathbf{x}$ \\
Nilai
\end{tabular} \\
\hline \multicolumn{6}{|c|}{ Opportunity } \\
\hline 1. & $\begin{array}{l}\text { Mengembangkan cokelat menjadi cemilan } \\
\text { yang sesuai dengan keinginan customer }\end{array}$ & 25 & 5 & 0,125 & 0,625 \\
\hline 2. & $\begin{array}{l}\text { Perkembangan teknologi \& informasi untuk } \\
\text { kepentingan promosi }\end{array}$ & 21 & 4 & 0,105 & 0,441 \\
\hline 3. & Dapat menembus pasar nasional & 21 & 4 & 0,105 & 0,441 \\
\hline 4. & Menjadi sponsor dalam berbagai event & 25 & 5 & 0,125 & 0,625 \\
\hline 5. & $\begin{array}{l}\text { Cokelat yang dapat dijadikan se bagai ha diah } \\
\text { atau souvenir }\end{array}$ & 25 & 5 & 0,125 & 0,625 \\
\hline \multicolumn{6}{|c|}{ Anc aman (Threats) } \\
\hline 1. & \begin{tabular}{|l} 
Banyaknya produk sejenis \\
\end{tabular} & 18 & 4 & 0,090 & 0,324 \\
\hline 2. & Adanya persaingan harga yang kompetitif & 16 & 3 & 0,080 & 0.256 \\
\hline 3. & $\begin{array}{l}\text { Tinglat kejenuhan customer terhadap } \\
\text { cokelat }\end{array}$ & 14 & 3 & 0.070 & 0,196 \\
\hline 4. & $\begin{array}{l}\text { Ada persepsi dari beberapa pihak meng enai } \\
\text { dampak konsumsi cokelat berlebih }\end{array}$ & 14 & 3 & 0,070 & 0,196 \\
\hline 5. & Brand kompetitor lebih dikenal & 21 & 4 & 0,105 & 0,441 \\
\hline & & 200 & & 1 & 4,170 \\
\hline
\end{tabular}

(Sumber: Pengolahan data, 2019)

Dari hasil perhitungan IFAS dan EFAS didapatkan nilai IFAS sebesar 3,9 dan nilai EFAS sebesar 4,1. Apabila dikonversikan ke dalam gambar Diagram IE Matriks, maka terletak di kuadran I.

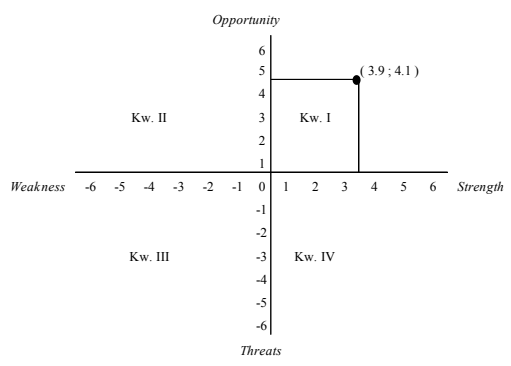

(Sumber: Pengolahan data, 2019)

Gambar 4.5 Diagram IE

\section{Marketing Mix}

Toko Kue Baper Cokelat memproduksi cokelat praline dengan berbagai macam karakter dan varian rasa.Semua produk cokelat praline yang dihasilkan Toko Kue Baper Cokelat dapat terserap oleh pasar dengan baik. Hal ini dikarenakan produk cokelat praline Toko Kue Baper Cokelat memiliki kualitas yang baik karena pengiriman dilakukan pada hari yang sama dan varian rasa yang beragam sehingga pilihan untuk customer semakin banyak.

Kisaran harga yang ditawarkan oleh Toko kue Baper Cokelat untuk Cokelat Praline sangat bervariasi diantara Rp 1.800 - Rp 10.000 per buah.

Toko Kue Baper Cokelat berada di Jalan Kemiri II Pondok Cabe Udik dimana area tersebut merupakan kawasan padat penduduk yang banyak dilalui pengguna jalan sehingga memudahkan konsumen untuk melakukan pemesanan.

Kegiatan promosi yang dilakukan oleh Toko Kue Baper Cokelat yaitu dengan cara memasarkan produk via sosial media, menyebarkan brosur, memberikan diskon harga, dan menyediakan pelayanan antar gratis untuk wilayah pondok cabe dan sekitarnya. Promosi yang dilakukan oleh Toko Kue Baper Cokelat juga dapat berupa spanduk yang dipasang di depan Toko.

\section{B. Aspek Teknis}

Penelitian ini dilakukan di Toko Kue Baper Cokelat yang terletak di Jalan Kemiri II No. 41, dengan bangunan seluas $44 \mathrm{~m} 2$. Beberapa variabel utama dalam penentuan lokasi suatu proyek antara lain ketersediaan bahan baku, suplai tenaga kerja, tenaga listrik dan air, fasilitas transportasi, dan letak pasar utama.

Toko Kue Baper Cokelattidak memiliki pemasok tetap dalam pengadaan bahan baku. Bahan baku utama yang dibutuhkan antara lain cokelat compound dan cokelat compound aneka rasa. Kebutuhan tersebut biasanya dibeli di Toko Gunung Mas dan Toko Karunia Gemilang di Jalan Benda Raya, Pamulang atau di Toko Hasan Plastik di daerah Wates, Pondok Cabe.

Jumlah pegawai keseluruhannya adalah 5 orang, dengan jumlah pegawai lakilaki sebanyak 1 orang, dan 4 orang pegawai perempuan. Pegawai di Toko Kue Baper Cokelat tidak mengalami kesulitan karena tenaga kerja terlebih dahulu dilatih untuk menghadapi pelanggan maupun kegiatan usaha.

Sumber daya listrik yang digunakan oleh Toko Kue Baper Cokelat berasal dari Perusahaan Listrik Negara (PLN), 
sedangkan sumber daya air yang digunakan berasal dari sumur air.

Pengangkutan bahan baku dari Toko bahan kue menuju Toko Kue Baper Cokelat menggunakan satu unit sepeda motor roda dua yang dilengkapi dengan box untuk penyimpanan barang.

Lokasi Toko Kue Baper Cokelat berada di Jalan Kemiri II No. 41 Pondok Cabe Udik, Pamulang, gang kemiri II ini berada di depan Universitas Terbuka Pondok Cabe. Proses produksi hingga kegiatan pemasarannya dilakukan pada satu tempat, yakni Toko Kue Baper Cokelat, agar mudah dilakukan pengawasan baik pada proses produksi maupun kualitas produk yang dihasilkan.

Toko Kue Baper Cokelat memiliki satu ruang utama yang memungkinkan para karyawan lebih mudah dalam menjalankan proses produksi. Lay-out Toko Kue Baper Cokelat dapat dilihat dalam Gambar 4.10

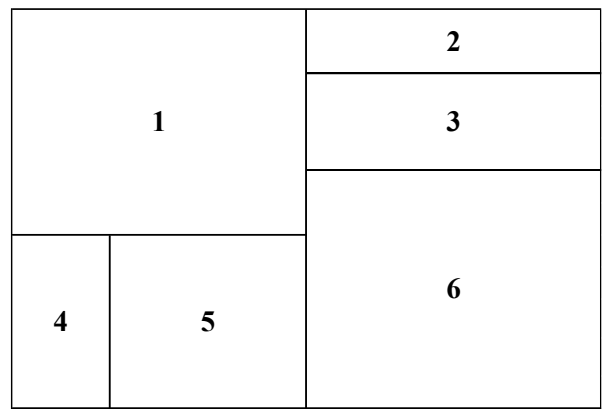

(Sumber: Toko Kue Baper Cokelat, 2019)

Gambar 4.10 Lay-out Bangunan

Keterangan:

1. Ruang Pengemasan

2. Tempat penyimpanan Barang Jadi

3. Tempat penyimpanan Bahan Baku

4. Toilet

5. Ruang Administrasi

6. Ruang produksi

Proses produksi cokelat praline menggunakan teknik double boiler dimana panci berisi air diletakkan di atas kompor, kemudian di atas panci tersebut diletakkan kembali wadah alumunium yang tahan panas. Kemudian, cokelat compound yang sudah dipotong dimasak hingga leleh dan siap untuk dicetak.

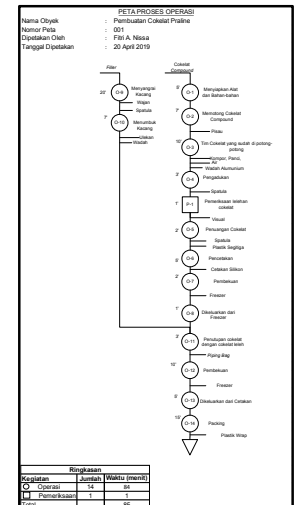

(Sumber: Pengolahan data, 2019)

Gambar 4.11 Peta Proses Operasi Cokelat Praline

Berdasarkan peta di atas, didapat hasil bahwa proses pembuatan cokelat praline dalam satu siklus memerlukan waktu sebanyak 422 detik atau 7,03 menit.

Perhitungan Kapasitas Produksi cokelat praline

a. Kapasitas Produksi per hari

Waktu produksi satu pes praline $=7$ menit $=0,1167 \mathrm{jam}$

Waktu kerja satu hari $=8$ jam

Pembuatan praline per hari $=4$ karyawan $\mathrm{x}$ waktu kerja/waktu produksi $=(4 \times 8$ jam) $/ 0,1167$ jam $=274,29 \mathrm{pcs}$

b. Kemampuan menghasilkan produk tiap bulan

Hasil produk tiap bulan $=$ Hasil produk tiap hari $\mathrm{x}$ rata-rata hari produksi $=$ $274,29 \times 25=6.857 \mathrm{pcs}$

c. Kemampuan menghasilkan produk tiap tahun

Hasil produk tiap tahun $=$ Hasil produk tiap bulan $\times 12$ bulan $=6.857$ pcs $\times 12=$ 85.577 pcs

Pengukuran waktu siklus, waktu normal dan waktu baku dalam proses pembuatan cokelat praline di Toko Kue Baper Cokelat

a. Perhitungan waktu siklus sudah didapat dari peta proses operasi dengan waktu kerja selama 8 jam dalam satu hari kerja. Proses pembuatan satu pcs cokelat praline memerlukan waktu sekitar 7,03 menit atau 422 detik

b. Diketahui waktu kerja 7 menit berdasarkan peta proses operasi produksi. Faktor performa dalam pengukuran waktu normal Toko Kue Baper Cokelat menggunakan P sebesar 1 karena operator diasumsikan bekerja 
dalam kondisi normal. Sehingga, didapat waktu normal sebesar:

$\mathrm{Wn}=7,03 \times 1=7,03$ menit.

c. Waktu baku produksi cokelat praline sebagai berikut:

Waktu baku $(\mathrm{Wb})=\mathrm{Wp}+\mathrm{I}$, kelonggaran 8 menit

$=7,03+8=15,03$ menit

\section{Aspek Keuangan}

\section{1) Total Project Cost}

Biaya proyeksi yang dimiliki Toko Kue Baper Cokelat memiliki Total Cost sebesar Rp101.852.000.

Tabel 4.9 Total Project Cost

\begin{tabular}{|c|c|c|c|c|c|}
\hline No & Deskripsi & Jumlah & Satuan & Harga Satuan (Rp) & Nilai Awal \\
\hline $1 \mathrm{r}$ & Perizinan & 1 & Lot & & $3,000,000$ \\
\hline $2 \mathrm{H}$ & Bangunan & 44 & $\mathrm{~m}^{2}$ & $1,750,000$ & $77,000,000$ \\
\hline $3 \mathrm{~s}$ & Sepeda Motor (bekas) & 1 & Unit & $8,500,000$ & $8,500,000$ \\
\hline \multicolumn{6}{|c|}{\begin{tabular}{l|l} 
& Mesin \\
\end{tabular}} \\
\hline & \begin{tabular}{|l|l|} 
a & Freezer \\
\end{tabular} & 1 & unit & $1,850,000$ & $1,850,000$ \\
\hline & \begin{tabular}{|l|l|}
$\mathrm{b}$ & Kulkas 2 pintu \\
\end{tabular} & 1 & unit & $2,500,000$ & $2,500,000$ \\
\hline & \begin{tabular}{|c|c|} 
c Air Conditioner \\
\end{tabular} & 1 & unit & $1,500,000$ & $1,500,000$ \\
\hline & d Standing Mixer & 2 & unit & 550,000 & $1,100,000$ \\
\hline & e Blender & 1 & unit & 450,000 & 450,000 \\
\hline & \begin{tabular}{|l|l|l|l|l}
$\mathrm{f}$ & Laptop \\
\end{tabular} & 1 & unit & $3,500,000$ & $3,500,000$ \\
\hline & \begin{tabular}{|l|l|}
$\mathrm{g}$ & Printer \\
\end{tabular} & 1 & unit & 450,000 & 450,000 \\
\hline \multicolumn{6}{|c|}{5 Peralatan } \\
\hline & \begin{tabular}{|l|l|} 
a & Alas potong \\
\end{tabular} & 2 & $\mathrm{pc}$ & 15,000 & 30,000 \\
\hline & \begin{tabular}{|l|l|} 
b & Baskom Stainless \\
\end{tabular} & 6 & $\mathrm{pc}$ & 20,000 & 120,000 \\
\hline & \begin{tabular}{|l|l|} 
c & Cetakan mika \\
\end{tabular} & 11 & pes & 15,000 & 165,000 \\
\hline & d Cetakan Silikon & 10 & pcs & 25,000 & 250,000 \\
\hline & \begin{tabular}{|l|l|l|l|l|l|l}
$f$ & Etalase \\
\end{tabular} & 1 & unit & 700,000 & 700,000 \\
\hline & $\mathrm{g}$ Gunting & 2 & pcs & 8,000 & 16,000 \\
\hline & h Kompor Gas 2 Tungku & 1 & unit & 450,000 & 450,000 \\
\hline & i Panci & 2 & unit & 40,000 & 80,000 \\
\hline & j j Pisau & 2 & pes & 15,000 & 30,000 \\
\hline & k Spatula & 2 & pcs & 5,000 & 10,000 \\
\hline & 1 Tabung Gas $3 \mathrm{Kg}$ & 1 & unit & 50,000 & 50,000 \\
\hline & m| Timbangan digital & 2 & unit & 35,000 & 70,000 \\
\hline \multicolumn{6}{|c|}{\begin{tabular}{l|l}
6 & Perlengkapan \\
\end{tabular}} \\
\hline & \begin{tabular}{l|l} 
a & Kertas Roti
\end{tabular} & 1 & pack & 15,000 & 15,000 \\
\hline & \begin{tabular}{|l|l|}
$b$ & Piping Bag
\end{tabular} & 1 & pack & 8,000 & 8,000 \\
\hline & \begin{tabular}{|c|c|} 
c & Tissue \\
\end{tabular} & 1 & pack & 8,000 & 8,000 \\
\hline
\end{tabular}

(Sumber: Toko Kue Baper Cokelat, 2019)

\section{2) Penyusutan}

Biaya penyusutan di Toko Kue

Baper Cokelat meliputi biaya penyusutan bangunan serta biaya penyusutan mesin dan peralatan. Metode perhitungan penyusutan menggunakan metode Garis Lurus (straightline method) . Biaya penyusutan per tahun sebesar Rp 9.892.157. Rincian biaya penyusutan dapat dilihat dalam Tabel 4.10

Tabel 4.10 Penyusutan

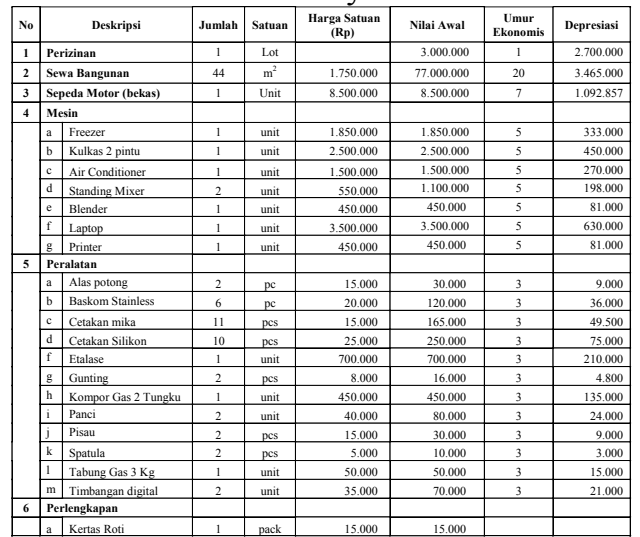

(Sumber: Pengolahan Penelitian, 2019)

\section{3) Rencana Penjualan}

Perencanaan Toko Kue Baper Cokelat menetapkan jumlah produk yang harus dibuat, jumlah persediaan bahan dan tenaga kerja, bahan baku yang akan dipakai, biaya produksi dan sebagainya untuk menjalankan aktifitasaktifitas perusahaan agar tujuan perusahaan tercapai. Dengan demikian, dapat dikatakan bahwa pelaksaan kegiatan di perusahaan bertitik tolak dari rencana penjualan sebagaimana yang dikemukakan pada Tabel 4.11

Tabel 4.11 Rencana Penjualan

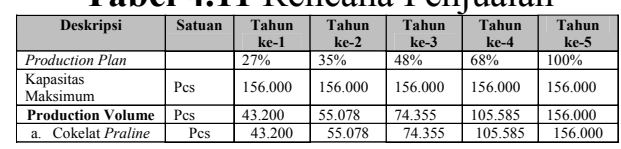

(Sumber: Pengolahan Penelitian, 2019

\section{4) Biaya Variabel}

Biaya Variabel terdiri dari Biaya Bahan Baku, Biaya Kemasan dan Biaya Tenaga Kerja.

Tabel 4.16 berikut ini merupakan biaya variabel dari cokelat praline 
Tabel 4.16 Biaya Variabel

\begin{tabular}{|c|c|c|c|c|c|c|c|}
\hline a. & Biaya Variabel & & Tahun 1 & Tahun 2 & Tahun 3 & Tahun 4 & Tahun 5 \\
\hline \multirow[t]{4}{*}{1} & Biaya Bahan Baku Langsung & & & & & & \\
\hline & & Cokelat Dark & Rp 7,776,000 & Rp 10,446,920 & Rp 14,861,396 & $\operatorname{Rp} 22,237,479$ & Rp 34,621,625 \\
\hline & & Cokelat White & Rp 4,320,000 & Rp 5,803,844 & Rp 8,256,331 & Rp $12,354,155$ & Rp 19,234,236 \\
\hline & & Cokelat Warna & $\operatorname{Rp} 1,080,000$ & $\operatorname{Rp} 1,450,961$ & $\operatorname{Rp} 2,064,083$ & $\operatorname{Rp} 3,088,539$ & $\operatorname{Rp} 4,808,559$ \\
\hline \multirow[t]{4}{*}{2} & Biaya Bahan Baku Pembantu & & & & & & \\
\hline & & Selai Cokelat & Rp $1,728,000$ & $\operatorname{Rp} 2,321,538$ & Rp 3,302,532 & Rp 4,941,662 & Rp 7,693,695 \\
\hline & & Kacang tanah kupas & Rp $1,900,800$ & $\operatorname{Rp} 2,553,691$ & Rp 3,632,786 & $\operatorname{Rp} 5,435,828$ & Rp 8,463,064 \\
\hline & & Isi gas elpiji & Rp 720,000 & Rp 967,307 & Rp 1,376,055 & $\operatorname{Rp} 2,059,026$ & Rp 3,205,706 \\
\hline \multirow[t]{5}{*}{3} & Biaya Kemasan & & & & & & \\
\hline & & Stik Permen & $\operatorname{Rp} 2,160,000$ & $\operatorname{Rp} 2,901,922$ & Rp 4,128,166 & Rp 6,177,077 & $\operatorname{Rp} 9,617,118$ \\
\hline & & Paper cup 5,5 cm & Rp $1,296,000$ & Rp $1,741,153$ & Rp 2,476,899 & Rp 3,706,246 & Rp 5,770,271 \\
\hline & & Plastik wrap & Rp 648,000 & Rp 870,577 & Rp $1,238,450$ & Rp 1,853,123 & $\operatorname{Rp} 2,885,135$ \\
\hline & & Box & Rp 4,320,000 & Rp 5,803,844 & Rp 8,256,331 & $\operatorname{Rp} 12,354,155$ & Rp 19,234,236 \\
\hline \multirow[t]{3}{*}{4} & Biaya Tenaga Kerja Langsung & & & & & & \\
\hline & & Produksi ( 2 orang) & $\operatorname{Rp} 30,000,000$ & $\operatorname{Rp} 31,500,000$ & Rp 33,075,000 & Rp $34,728,750$ & Rp 36,465,188 \\
\hline & & Packing (1 orang) & Rp 15,000,000 & Rp 31,500,000 & Rp 33,075,000 & Rp $34,728,750$ & Rp 36,465,188 \\
\hline & & Jumlah Biay & Rp70,948,800 & Rp97,861,758 & Rp115,743,029 & Rp143,664,790 & Rp188,464,021 \\
\hline
\end{tabular}

(Sumber: Pengolahan Penelitian, 2019)

5) Biaya Tetap

Biaya Tetap merupakan biaya produksi yang tidak masuk dalam biaya bahan baku maupun biaya tenaga kerja langsung. Biaya tetap toko kue baper cokelat dapat dilihat pada Tabel 4.17

Tabel 4.17 Biaya Tetap

\begin{tabular}{|c|c|c|c|c|c|c|c|}
\hline No & Komponen & Jumlah & $\begin{array}{l}\text { Harga } \\
\text { Satuan }\end{array}$ & \multicolumn{2}{|c|}{ Harga bulan } & \multicolumn{2}{|c|}{ Harga /tahun } \\
\hline 1 & $\begin{array}{l}\text { Biaya Air } \\
\end{array}$ & $10 \mathrm{ha}$ & $\operatorname{Rp} 5.000$ & & 50.000 & & 600.000 \\
\hline 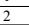 & Biaya Listrik & $60 \mathrm{kWh}$ & $\operatorname{Rp} 1.700$ & $\mathrm{Rp}$ & 102.000 & $\mathrm{Rp}$ & 1.224 .000 \\
\hline 3 & Biaya Pulsa & & & & 150.000 & $\mathrm{Rp}$ & 1.800 .000 \\
\hline 4 & \begin{tabular}{|l|} 
Biaya Transport \\
\end{tabular} & & & & 200.000 & $\mathrm{Rp}$ & 2.400 .000 \\
\hline 5 & $\begin{array}{l}\text { Biaya Tenaga } \\
\text { Kerja Tidak } \\
\text { Langsung }\end{array}$ & & & & 2.000 .000 & $\mathrm{Rp}$ & 24.000 .000 \\
\hline 6 & \begin{tabular}{|l|} 
Perawatan, \\
kabershon
\end{tabular} & & & $\mathrm{Rp}$ & 100.000 & $\mathrm{Rp}$ & 1.200 .000 \\
\hline 7 & ATK & & & & 50.000 & $\mathrm{Rp}$ & 600.000 \\
\hline 8 & $\begin{array}{l}\text { Biaya tak } \\
\text { terduga }\end{array}$ & & & $\mathrm{Rp}$ & 41.667 & $\mathrm{Rp}$ & 500.000 \\
\hline 9 & $\begin{array}{l}\text { Biaya } \\
\text { Pemeliharaan } \\
\text { Mesin }\end{array}$ & & & $\mathrm{Rp}$ & 133.333 & $\mathrm{Rp}$ & 1.600 .000 \\
\hline 10 & $\begin{array}{l}\text { Biaya Perawatan } \\
\text { Kendaraan }\end{array}$ & & & $\mathrm{Rp}$ & 300.000 & $\mathrm{Rp}$ & 3.600 .000 \\
\hline 11 & $\begin{array}{l}\text { Biaya Tetap } \\
\text { Penyusutan }\end{array}$ & & & $\mathrm{Rp}$ & 261.321 & $\mathrm{Rp}$ & 3.135 .857 \\
\hline 12 & $\begin{array}{l}\text { Biaya Tetap Non } \\
\text { Penyusutan }\end{array}$ & & & & 513.750 & $\mathrm{Rp}$ & 6.165 .000 \\
\hline
\end{tabular}

(Sumber: Pengolahan Penelitian, 2019)

\section{6) Harga Pokok Produksi}

Harga pokok produksi adalah penjumlahan seluruh pengeluaran sumber ekonomi yang digunakan untuk mengubah bahan baku menjadi produk. Perhitungan harga pokok produksi dapat digunakan untuk menentukan harga jual yang akan diberikan kepada pelanggan Harga pokok produksi Toko Kue Baper Cokelat dapat dilihat pada Tabel 4.19

Tabel 4.19 Harga Pokok Produksi

\begin{tabular}{|c|c|c|c|c|c|}
\hline Uraian & Tahun ke-1 & Tahun ke-2 & Tahun ke-3 & Tahun ke-4 & Tahunke-5 \\
\hline Penjualan & 43.200 & 55.078 & 74.355 & 105.585 & 156.000 \\
\hline $\begin{array}{l}\text { Total Fixed } \\
\text { Cost }\end{array}$ & Rp46,824,857 & Rp46,824,857 & Rp46,824,857 & Rp46,824,857 & Rp46,824,857 \\
\hline $\begin{array}{l}\text { Total } \\
\text { Variable } \\
\text { Cost }\end{array}$ & Rp70.948.800 & Rp97.86 & Rp1 13.9 & Rp139. & $\begin{array}{l}8 \\
8 \text { Rp165 }\end{array}$ \\
\hline \begin{tabular}{l|} 
Biaya \\
Pemasaran \\
\end{tabular} & Rp3.000.000 & Rp3.150.000 & Rp3.307.50 & Rp3.472.875 & Rp3.646.51 \\
\hline Total Biaya & Rp120, & Rp147,836,615 & Rp165,8 & \begin{tabular}{|l} 
Rp193,962,522 \\
\end{tabular} & \begin{tabular}{|l|l|l}
22 & 2238,935,397
\end{tabular} \\
\hline HPP & Rp 2,795.69 & $\operatorname{Rp} 2,684.13$ & $\operatorname{Rp} 2,230.85$ & \begin{tabular}{|l|} 
Rp $1,837.04$ \\
\end{tabular} & Rp 1,531.64 \\
\hline ual & 3,000 & 3,0 & 3,000 & 3,000 & 3,000 \\
\hline $\begin{array}{l}\text { Margin } \\
\text { Keuntung }\end{array}$ & & $11 \%$ & $34 \%$ & $63 \%$ & $96 \%$ \\
\hline
\end{tabular}

(Sumber: Pengolahan Penelitian, 2019)
7) Total Manufacturing Overhead Cost

Biaya-biaya yang terjadi dalam perusahaan manufaktur disebut biaya manufaktur atau biaya pabrik. Biaya pabrik atau manufaktur terdiri atas biaya bahan baku, tenaga kerja langsung dan biaya overhead pabrik. Biaya manufaktur tiap tahunnya dapat dilihat pada Tabel 4.20

\section{Tabel 4.20 TMOH}

\begin{tabular}{|l|l|l|l|l|l|}
\hline & Tahun ke-1 & Tahun ke-2 & Tahun ke-3 & Tahun ke-4 & Tahun ke-5 \\
\hline $\begin{array}{l}\text { Total } \\
\text { Manufacturing } \\
\text { Overhead Cost }\end{array}$ & 120 & $\mathrm{Rp}$ & $\mathrm{Rp}$ & $\mathrm{Rp}$ & $\mathrm{Rp}$ \\
\hline
\end{tabular}

(Sumber: Pengolahan Penelitian, 2019)

Berdasarkan tabel di atas, pada tahun pertama total biaya yang dikeluarkan sebesar Rp 120,773,657. Perhitungan tersebut berdasarkan harga bahan baku pada tahun pertama dijumlahkan dengan biaya tenaga kerja langsung dan biaya overhead.

TMOH1 $=$ Total Raw Material + Direct Labour + Factory Overhead + Biaya Pemasaran

$=\mathrm{Rp} 25.948 .800+\mathrm{Rp} 45.000 .000+\mathrm{Rp}$ $46.824 .857+\mathrm{Rp} 3.000 .000$

$=\operatorname{Rp} 120.773 .657$

\section{Analisis Kelayakan Usaha}

\section{Average Rate of Return}

Average Rate of Return atau Accounting Rate of Return merupakan metode tingkat pengembalian rata-rata yang mengukur berapa tingkat keuntungan rata-rata yang diperoleh dari sebuah investasi. Dalam menghitung ARR secara matematis, menggunakan rumus sebagai berikut: 


$$
\begin{aligned}
& \text { Average EAT }=\frac{\sum E A T}{n} \\
& =\frac{R p 369,979,415}{5} \\
& =\mathrm{Rp} 73,995,883 \\
& \begin{aligned}
\text { Average Investment } & =\frac{\text { Initial Investment }}{2} \\
& =\frac{112.037 .200}{2} \\
& =R p 56.018 .600 \\
A R R=\frac{\text { Average EAT }}{\text { Average Investment }} \times 100 \% & \\
= & \frac{73,995,883}{56,018,600} \times 100 \% \\
= & 132,09 \%
\end{aligned}
\end{aligned}
$$

Dari perhitungan di atas dapat diketahui bahwa ARR Toko Kue Baper Cokelat adalah sebesar 132,09\%, jika dibandingkan dengan tingkat cost of capital maka nilai ARR lebih besar. Diketahui tingkat cost of capital yaitu sebesar 7,37\%. Maka, usaha Toko Kue Baper Cokelat ini layak untuk dijalankan.

\section{Net Present Value}

NPV merupakan salah satu alat yang digunakan untuk menilai apakah sebuah investasi yang dilakukan dapat menguntungkan atau tidak. Nilai discount factor bisa didapatkan dari tabel bunga atau dapat dihitung secara manual menggunakan rumus:

$$
D F=\frac{1}{(1+r)^{n}}
$$

Tingkat suku bunga yang digunakan pada perhitungan NPV Toko Kue Baper Cokelat, merupakan tingkat suku bunga BI (Bank Indonesia) per Juli 2019 yakni sebesar 5,75\%. NPV Toko Kue Baper Cokelat dapat dilihat pada Tabel 4.22

Tabel 4.22 Net Present Value

\begin{tabular}{|c|c|c|c|}
\hline No & DF (5,75\%) & Proceeds & PV of Proceeds \\
\hline 1 & 0,9456 & $10.638 .248,57$ & $10.059 .809,52$ \\
\hline 2 & 0,8942 & $17.923 .634,45$ & $16.027 .483,03$ \\
\hline 3 & 0,8456 & $51.747 .793,65$ & $43.757 .319,45$ \\
\hline 4 & 0,7996 & $107.508 .254,96$ & $85.964 .730,97$ \\
\hline 5 & 0,7561 & $215.155 .609,37$ & $162.686 .229,16$ \\
\hline Total $P$ V of Proceed & & $\mathbf{3 1 8 . 4 9 5 . 5 7 2 , 1 4}$ \\
\hline Total PV of outlays & $\mathbf{1 0 1 . 8 5 2 . 0 0 0 , 0 0}$ \\
\hline \multicolumn{2}{|l|}{ NPV } & $\mathbf{2 1 6 . 6 4 3 . 5 7 2 , 1 4}$ \\
\hline
\end{tabular}

(Sumber: Pengolahan Penelitian, 2019)

\section{Profitability Index}

Profitability Index atau bisa juga

\begin{tabular}{|c|c|c|c|}
\hline \begin{tabular}{|l|l} 
No \\
\end{tabular} & DF $(5,75 \%)$ & Proceeds & PV of Proceeds \\
\hline 1 & 0.9456 & $10,638,248.57$ & $10,059,809.52$ \\
\hline 2 & 0.8942 & $17,923,634.45$ & $16,027,483.03$ \\
\hline 3 & 0.8456 & $51,747,793.65$ & $43,757,319.45$ \\
\hline 4 & 0.7996 & $107,508,254.96$ & $85,964,730.97$ \\
\hline 5 & 0.7561 & $215,155,609.37$ & $162,686,229.16$ \\
\hline \multicolumn{3}{|c|}{ Total PV of Proceed } & $318,495,572.14$ \\
\hline \multirow{2}{*}{\multicolumn{3}{|c|}{ Total PV of outlays }} & $101,852,000.00$ \\
\hline & & NPV & $216,643,572.14$ \\
\hline \multicolumn{3}{|c|}{ Profitability Index } & 3.13 \\
\hline \multicolumn{3}{|c|}{ Keterangan } & Layak \\
\hline
\end{tabular}
disebut Net B/C merupakan salah satu metode capital budgeting dimana perhitungan yang dilakukan merupakan perbandingan antara nilai sekarang penerimaan kas bersih masa mendatang dengan nilai sekarang investasi. Hasil perhitungan PI pada Toko Kue Baper Cokelat dapat dilihat pada Tabel 4.23

Tabel 4.23 Profitability Index

(Sumber: Pengolahan Penelitian, 2019)

Berdasarkan tabel di atas, Profitability Index yang didapat sebesar 1.38, yang berarti PI $>1$, maka usaha Toko Kue Baper Cokelat layak untuk dijalankan.

\section{Internal Rate of Return}

Internal Rate of Return (IRR) adalah suatu nilai suku bunga yang membuat nilai NPV proyek sama dengan nol, atau tingkat suku bunga yang menunjukkan jumlah NPV sama dengan jumlah keseluruhan ongkos investasi proyek. Perhitungan IRR dilakukan dengan cara trial and error (coba-coba), yaitu melalui langkah percobaan dengan cara acak menggunakan tingkat faktor discount sehingga nilai NPV sama dengan 0 . Telah diketahui nilai faktor discount adalah $5,75 \%$, percobaan dengan cara trial and error secara acak sebingga didapatkan nilai NPV positif pada discount rate $5,75 \%$ secara lebih rinci dalam Tabel 4.24

Tabel 4.24 NPV dengan DF 5,75\%

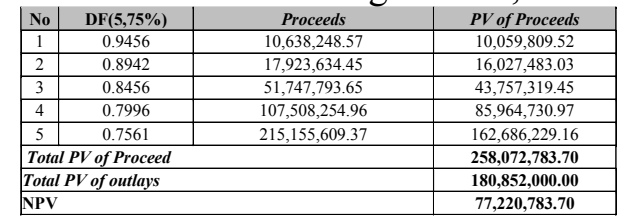

(Sumber: Pengolahan Penelitian, 2019)

Untuk menghitung Indikator tingkat investas yang mana perkembangan tingkat investasi dari tahun ke tahun berbeda-beda, oleh karena itu suku bunga yang berbeda dipilih dua rating 
dengan metode trial and error. Tabel 4.25 menunjukkan NPV bernilai negatif.

Tabel 4.25 NPV dengan DF 41\%

\begin{tabular}{|c|c|c|c|}
\hline No & DF (41\%) & Proceeds & PV of Proceeds \\
\hline 1 & 0.8621 & $10,638,249$ & $7,544,857$ \\
\hline 2 & 0.7432 & $17,923,634$ & $9,015,459$ \\
\hline 3 & 0.6407 & $51,747,794$ & $18,460,119$ \\
\hline 4 & 0.5523 & $107,508,255$ & $27,199,778$ \\
\hline 5 & 0.4761 & $215,155,609$ & $38,606,205$ \\
\hline Total PV of Proceed & & $100,826,418$ \\
\hline Total PV of outlays & & $101,852,000$ \\
\hline \multicolumn{2}{|l|}{ NPV } & $(1,025,582)$ \\
\hline
\end{tabular}

(Sumber: Pengolahan Penelitian, 2019)

Dari tabel di atas, NPV yang bernilai negatif berada di tingkat suku bunga $41 \%$. Langkah berikutnya yaitu menghitung IRR dengan rumus sebagai berikut:

$\mathrm{IRR}=\mathrm{rr}+\left[[(\mathrm{NPV})] \_\mathrm{rr} /\left([\mathrm{TPVProceeds}) \_\mathrm{rr}-\right.\right.$ [TPV Proceeds $\rrbracket$ rt $) \times($ rt-rr $)]$

Sehingga, diperoleh:

IRR $=5,75 \%+[77,220,783.70 /(258,072,7$

$83.70-100,826,418) \times(41 \%-5,75 \%]$

IRR $=0,0575+[77,220,783.70 / 157,246,36$

$6 \times 0,3525]$

IRR $=0,0575+[0,4911 \times 0,3525]$

$\mathrm{IRR}=0,0575+0,1731$

IRR $=0,2306=23,06 \%$

Berdasarkan hasil perhitungan di atas, didapatkan nilai IRR sebesar $23,06 \%$. Hal ini menunjukkan bahwa investasi ini layak karena IRR > tingkat suku bunga terendah yakni $23,06 \%>$ $5,75 \%$. Nilai ini lebih besar dari suku bunga yang berlaku yaitu 5,75\%, sehingga usaha ini dinyatakan layak untuk dijalankan.

\section{Payback Period}

Payback Period digunakan untuk menghitung lama periode yang diperlukan untuk mengambalikan uang yang telah diinvestasikan. Penilaian terhadap jangka waktu pengembalian investasi uatu proyek atau usaha. Perhitungan ini dapat dilihat dari perhitungan kas bersih yang diperoleh setiap tahun menggambarkan payback period Toko Kue Baper Cokelat pada Tabel 4.27

Tabel 4.27 Cash flow

\begin{tabular}{|l|l|l|l|l|l|}
\hline & Tahun ke-1 & Tahun ke-2 & Tahun ke-3 & Tahun ke-4 & Tahun ke-5 \\
\hline \multirow{2}{*}{ Cash Flow } & $\mathrm{Rp}$ & $\mathrm{Rp}$ & $\mathrm{Rp}$ & $\mathrm{Rp}$ & $\mathrm{Rp}$ \\
& 7.735 .427 & 15.020 .813 & 43.383 .789 & 94.173 .539 & 165.763 .508 \\
\hline
\end{tabular}

(Sumber: Pengolahan Penelitian, 2019)

Berdasarkan tabel di atas, dana yang diinvestasikan akan diperoleh kembali seluruhnya dalam waktu 3 tahun 0,2 bulan, hal tersebut berdasarkan perhitungan berikut:

\begin{tabular}{ll}
$101,852,000$ & $\begin{array}{l}\text { Total Project Cost } \\
\text { Pengurangan }\end{array}$ \\
\hline $10,638,249$ & Cashflow I \\
$11,213,751$ & Pengurangan \\
$17,923,634$ & Cashflow II \\
\hline $73,290,117$ & Pengurangan \\
$51,747,794$ & Cashflow III \\
\hline $21,542,323$ & Pengurangan \\
$107,508,255$ & Cashflow IV \\
$(85,965,932)$ & Pengurangan \\
$215,155,609$ & Cashflow V
\end{tabular}

(Sumber: Pengolahan Penelitian, 2019)

Pada perhitungan di atas, tampak akumulasi kas masuk (nol) terletak antara tahun ke-3 dan tahun ke-4 sehingga Payback Period akan berada pada tahun-tahun tersebut. Karena alur kas pertahun tidak sama, maka rumus yang digunakan ialah sebagai berikut:

$\mathrm{PP}=\mathrm{Tahun}$ Pengurang $+[(($ Nilai sisa uang investasi $/($ Cash flow berikutnya)) $\mathrm{x} 1$ tahun]

$\mathrm{PP}=3+[((21.542 .323) /(107.508 .255$

))x 1 tahun]

$\mathrm{PP}=3+0,2$ tahun

$\mathrm{PP}=3,2$ tahun

Dengan demikian, Payback Period dari Toko Kue Baper Cokelat adalah 4,12 tahun dengan $0,2 \times 365=73$ hari, dengan asumsi 1 bulan $=30$ hari, maka 73 hari $=2,43$ bulan $=0,43$ bulan $\times 30$ 
hari $=12,9$ hari. Ini berarti dana yang diinvestasikan sudah akan diperoleh kembali seluruhnya dalam waktu 3 tahun 2 bulan 13 hari, yang mengindikasikan bahwa usaha yang dilakukan Toko Kue Baper Cokelat adalah layak.

\section{KESIMPULAN}

Dari hasil analisa data dan pembahasan yang telah diuraikan pada bab sebelumnya, penulis dapat mengambil kesimpulan yaitu :

1. Dilihat pada segi pasar dan segi pemasaran, dari segi teknis dan segi finansial pada Toko Kue Baper Cokelat adalah sebagai berikut:

a. Pada segi Pasar dan Pemasaran, Toko Kue Baper Cokelat mendapatkan hasil sebagai berikut:

1) Potensi pasar cokelat praline setiap tahunnya mengalami peningkatan, sehingga membuka peluang untuk melakukan pengembangan usaha,

2) Berdasarkan hasil pembobotan pada Analisis SWOT, Toko Kue Baper Cokelat berada di kuadran I yang berarti Toko Kue Baper Cokelat memiliki peluang dan kekuatan sehingga dapat memanfaatkan peluang yang ada.

3) Bauran Pemasaran Cokelat Praline Toko Kue Baper Cokelat mendapatkan hasil yakni:

a) Produk, cokelat praline dapat disajikan dalam berbagai bentuk dan rasa sehingga konsumen tidak merasa bosan.Logo dan Label Cokelat Praline dibuat se-sederhana mungkin agar mudah diingat oleh konsumen,

b) Price, harga Cokelat Praline Toko Kue Baper Cokelat masih bisa bersaing dengan produsen lain,sehingga memungkinkan dilakukan perekrutan reseller

c) Place, lokasi pendirian usaha Cokelat Praline berada di kawasan padat penduduk. Selain itu, Toko Kue Baper Cokelat sudah dapat diakses melalui platform google maps. Sehingga, memudahkan pencarian lokasi.

d) Promosi, untuk memudahkan pemesanan cokelat, Toko Kue Baper Cokelat menyediakan beberapa sosial media yang dapat diakses konsumen diantaranya: WhatsApp dan Instagram

b. Pada segi Teknis, penelitian ini mendapatkan beberapa hasil, diantaranya:

1) Lokasi Usaha, terletak di Jalan Kemiri Raya II No. 41 (Seberang Universitas Terbuka), Pondok Cabe Udik, Pamulang

2) Ketersediaan Bahan Baku, Supplier bahan baku pembuatan cokelat praline berada di daerah Wates, yakni Toko Hasan Plastik dan Toko Gunung Mas di daerah pondok benda.

3) Suplai Tenaga Kerja, Toko Kue Baper Cokelat menyerap tenaga kerja yang berasal dari daerah sekitar. Tenaga Kerja yang dimiliki oleh Toko Kue Baper Cokelat sejumlah 5 (lima) orang, yang seluruhnya merupakan masyarakat sekitar toko.

4) Sumber Daya Listrik dan Air, biaya listrik dan air yang dikeluarkan oleh Toko Kue Baper Cokelat tiap bulannya sebesar 100.000 rupiah

5) Fasilitas Transportasi, untuk memudahkan pembelian bahan baku dan pengiriman pesanan, Toko Kue Baper Cokelat menyediakan 1 (satu) unit sepeda motor yang dilengkapi 
keranjang pada bagian kanan dan kirinya.

6) Letak Pasar Utama, Toko Kue Baper Cokelat berada di lokasi pemukiman padat penduduk dimana lokasi toko ini cepat dan mudah dijangkau kemudian aksesnya dekat dengan sekolah-sekolah.

7) Tata Letak, Toko Kue Baper Cokelat memiliki 5(lima) ruangan, dimana ruang terdepan merupakan ruang packing, dimana pada ruangan tersebut terdapat rak display untuk meletakkan cokelat yang siap untuk dikirim.

8) Proses Produksi Cokelat Praline menggunakan teknik double boiler dimana untuk melelehkan cokelat compound diperlukan dua jenis panci yang berbeda ukuran agar cokelat yang sedang dalam proses pelelehan tidak terkena uap air. Pada Peta Proses Operasi didapati operasi sebanyak 16 kali dan pemeriksaan 1 kali. Pada Peta Aliran Proses, terdapat operasi sebanyak 12 kali, pemeriksaan 1 kali, transportasi sebanyak 2 kali, dan aktivitas menunggu sebanyak 3 kali. Jarak total yang diperoleh berdasarkan Peta Aliran Proses yakni 5,5 $\mathrm{m}$.

9) Pengukuran Waktu, didapat waktu siklus sebesar 7,03 menit, waktu baku sebesar 15,03 menit dan waktu normal sebesar 7,03 menit.

c. Pada segi Finansial, diperoleh hasil sebagai berikut:

1) Modal awal yang digunakan Toko Kue Baper Cokelat sebesar Rp 101.852.000 yang berasal dari dana gabungan antar pemilik.

2) Penyusutan sebesar Rp 9.892.157 per tahun

3) Produksi dan Perencanaan Penjualan tiap tahunnya selama lima tahun berturutturut yakni 43.200 pcs, 55.078 pcs, 74.355 pcs, 105.585 pcs dan 156.000 pcs.

4) Biaya Bahan Baku yang diperlukan selama satu tahun bervariasi, yakni:

a) Pada tahun pertama, biaya bahan baku yang diperlukan sebesar $\quad \mathrm{Rp}$ $25,948,800$

b) Pada tahun kedua, biaya bahan baku yang diperlukan sebesar Rp 34,861,758

c) Pada tahun ketiga, biaya bahan baku yang diperlukan sebesar Rp 49,593,029

d) Pada tahun keempat, biaya bahan baku yang diperlukan sebesar $\mathrm{Rp}$ $74,207,290$

e) Pada tahun kelima, biaya bahan baku yang diperlukan sebesar $\quad \mathrm{Rp}$ $115,533,646$

5) Biaya Tenaga Kerja Langsung sebesar Rp 1.250.000 per bulan dan mengalami kenaikan sebesar $5 \%$ per tahun.

6) Biaya Tetap yang dikeluarkan oleh Toko Kue Baper Cokelat yakni sebesar $\mathrm{Rp}$ 3.902.071 per bulan atau setara dengan Rp 46.824.857per tahun.Biaya tersebut digunakan untuk memenuhi kebutuhan diluar produksi cokelat praline, seperti Pengeluaran Air, Beban Listrik, Beban Pulsa, Beban Transport, Beban Tenaga Kerja Tidak Langsung, Perawatan, kebersihan, ATK, Beban tak terduga, Beban Pemeliharaan Mesin, Beban Perawatan Kendaraan, Beban Tetap Penyusutan, Beban Tetap Non Penyusutan.

7) Harga Jual, Cokelat Praline Toko Kue Baper Cokelat dijual dengan harga $\mathrm{Rp} 3.000$ per pcs. Harga tersebut sudah 
termasuk kotak pakcaging. Harga cokelat praline bervariasi tergantung pada rasa dan varian yang dipilih.

8) Harga Pokok Produksi Cokelat Praline pada tahun pertama yakni sebesar Rp 120,773,657, pada tahun ke-dua sebesar Rp147,836,615, pada tahun ketiga sebesar Rp165,875,386, pada tahun ke-empat dengan jumlah Rp193,962,522, dan pada tahun ke-limadengan jumlah Rp238,935,397.

9) Total Manufacturing Overhead Cost Toko Kue Baper Cokelat pada tahun pertama sebesar Rp 120,773,657, pada tahun kedua sebesar Rp 147,836,615, pada Tahun ketiga sebesar Rp 165.875.386, pada tahun keempat sebesar Rp 193.962.522, dan pada tahun kelima sebesar Rp 238.935.397

2. Penerapan metode Capital Budgeting pada Analisis Kelayakan Usaha Cokelat Praline mendapat hasil sebagai berikut:

a. Average Rate of Return

Berdasarkan hasil penelitian, didapat ARR sebesar 132,09\% yang mana angka tersebut lebih besar daripada tingkat cost of capital yakni $7,37 \%$. Hal ini menandakan bahwa usaha cokelat praline Toko Kue Baper Cokelat layak untuk dijalankan.

b. Net Present Value

Berdasarkan hasil penelitian, didapat PV Cash Inflow dengan discount factor 5,75\% sebesar Rp 318.495.572,14, dengan PV of Investment $\mathrm{Rp} \quad 101.852 .000$ menghasilkan NPV sebesar Rp 216,643,572.14. Maka dengan ini proposal investasi bisa diterima dan usaha ini pantas untuk dijalankan dengan nilai NPV $>1$.

c. Profitability Index

Dari hasil perhitungan, didapat nilai PI sebesar 3.13, hal ini menunjukkan bahwa usaha cokelat praline Toko Kue Baper
Cokelat layak dijalankan, karena PI $>1$.

d. Internal Rate of Return (IRR)

Hasil perhitungan dengan metode tingkat investasi (IRR), proposal investasi pants untuk dilakukan dengan nilai IRR $23,06 \%$. Dengan tingkat suku bunga terendah yakni $5,75 \%$, maka nilai ini lebih besar.

e. Payback Period

Berdasarkan perhitungan payback period, didapatkan hasil investasi akan dapat return dalam jangka waktu 3 tahun 2 bulan 13 hari. Hasil ini menunjukkan bahwa proposal investasi ini pantas dilaksanakan dengan masa payback period lebih cepat dibandingkan umur investasi mesin yaitu 5 tahun.

\section{DAFTAR PUSTAKA}

Aditya,S.dkk (2014). Analisis Kelayakan Usaha Lemari/Rak

Simple and Easy Delivery Di Kecamatan Cikarang, Jurnal Teknik Industri, Institut Teknologi Nasional.

\begin{tabular}{|c|c|}
\hline Alma,Buchori & (2010). \\
\hline $\begin{array}{l}\text { Bisnis, } \\
\text { Bandung. }\end{array}$ & Penerbit \\
\hline
\end{tabular}

Busro, M.(2017). Studi Kelayakan Bisnis,Penerbit Graha Ilmu, Jakarta.

Chandra,A.C.dkk (2016). Analisis Kelayakan Usaha Pengolahan Susu Sapi Di Kota Wisata Batu Malang, Jurnal Teknik Industri, Institut Teknologi Nasional.

Erliana, C.I.(2015).Bahan Ajar Analisis dan Pengukuran Kerja. Penerbit Universitas Malikussaleh,Aceh. 


\section{Huda,F.H.(2014). Studi Kelayakan Pendirian Industri Tepung Singkong Modifikasi (Mocaf) Di Kabupaten Bogor, Jurnal Teknologi Industri Pertanian, Institut Pertanian Bogor.}

Hurriyati,R.I. (2015). Bauran Pemasaran \& Loyalitas Konsumen, Penerbit Alfabeta, Bandung.

Irawan,S.(2014). Manajemen Pemasaran Modern, Penerbit Prenada Media Group,Yogyakarta.

Kasmir, (2017). Studi Kelayakan Bisnis, Penerbit Prenada Media Group,Yogyakarta.

Kertajaya,H.dkk.(2016). Syariah Marketing, Penerbit Mizan, Bandung.

Khotimah, H.dkk.(2014). Analisis Kelayakan Finansial Usaha Budidaya Bambu,Jurnal Ilmu Kehutanan, Pusat Peningkatan Produktivitas Hutan, Badan Penelitian, Pengembangan, dan Inovasi Kementerian Lingkungan Hidup dan Kehutanan.

Kotler, (2009). Marketing, Penerbit Erlangga, Jakarta.

Naryoto, P.dkk.(2014). “Analisis Studi Kelayakan Pendirian Usaha "Minuman Segar Jus Buah Dan Pop Ice” di Ciledug Ditinjau dari Capital Budgeting Periode Tahun 2014 - 2018, Jurnal Ekonomi, Universitas Budi Luhur.

Rangkuti, Freddy. (2013). Analisis SWOT. Penerbit Gramedia Pustaka, Jakarta

Riyanto, Bambang.(2010).Dasar-Dasar Pembelanjaan Perusahaa Ed.4,Penerbit
BPFE,

Yogyakarta.

Sinaga,D

Kewirausahaan:Pedoman praktis untuk Kalangan Profesi dan Mahasiswa, Penerbit Alfabeta, Bandung.

Suratmono, (2017).Pedoman Cokelat.Direktorat Standardisasi Produk Pangan, Jakarta.
Sutalaksana,I.Z.(2006) Teknik Perancangan Sistem Kerja, Penerbit ITB, Bandung

Tjiptono,Fandy. (2016). Strategi Pemasaran, Penerbit Andi Yogyakarta.

Yuniarta,G.A.dkk(2015). Kewirausahan dan Aspek-Aspek Studi Kelayakan Usaha, Penerbit Graha Ilmu, Jakarta.

http://www.bps.go.id , diakses pada tanggal 18 Oktober 2018, pukul 14:35 